\title{
Leadership Structure and Corporate Governance in Switzerland
}


The Author(s):

Dr. Markus M. Schmid

Swiss Institute of Banking and Finance

University of St. Gallen

CH-9000 St. Gallen

markus.schmid@unisg.ch

\section{Prof. Dr. Heinz Zimmermann}

Center of Business and Economics (WWZ), University of Basel

Holbeinstrasse 12

CH-4051 Basel

heinz.zimmermann@unibas.ch

A publication oft the Center of Business and Economics (WWZ), University of Basel.

(C) WWZ Forum 2007 and the author(s). Reproduction for other purposes than the personal use needs the permission of the author(s).

\section{Contact:}

WWZ Forum | Petersgraben 51 | CH-4003 Basel | forum-wwz@unibas.ch |www.wwz.unibas.ch 


\title{
Leadership Structure and Corporate Governance in Switzerland*
}

\author{
Markus M. Schmid ${ }^{\mathrm{a} \#}$ and Heinz Zimmermann ${ }^{\mathrm{b}}$ \\ ${ }^{a}$ Swiss Institute of Banking and Finance, University of St. Gallen, CH-9000 St. Gallen, \\ Switzerland \\ ${ }^{b}$ Department of Finance, University of Basel, CH-4051 Basel, Switzerland
}

Version: May 15, 2007

\begin{abstract}
The question of whether the CEO should also serve as chairman of the board is one of the most hotly debated issues in the recent corporate governance discussion. While agencytheoretic arguments advocate a separation of decision and control functions, the empirical evidence focusing on U.S. companies is not conclusive. In this context evidence from a country with a different practice of CEO succession may provide important new insights with respect to the question of whether one leadership structure should generally be preferred to the other one. This article fills this gap by investigating the valuation effects of leadership structure in Switzerland where - in contrast to the U.S. - a separation of the CEO and chairman functions is common.
\end{abstract}

Consistent with the majority of prior research focusing on the U.S., the authors found no evidence of a systematic and significant difference in valuation between firms with combined and firms with separated functions. They also investigated whether leadership structure is related to firm-level corporate governance characteristics and found a similar curvilinear relationship between leadership structure and managerial shareholdings as is observed between firm value and managerial shareholdings. An implication is that possible agency costs associated with a combined function are mitigated by a higher incentive alignment of the CEO/chairman through an adequate level of managerial shareholdings.

Over the last few years corporate governance became an important investment criterion, which is for example reflected in the emergence of various corporate governance ratings. The authors of this article additionally investigated whether firm value is significantly related to firm level corporate governance as measured by a broad survey-based index for a representative sample of Swiss firms. They documented a positive and significant relationship between the corporate governance index and firm valuation. This finding is robust to controlling for a series of additional governance mechanisms related to ownership structure, board characteristics, and leverage as well as a potential endogeneity of these mechanisms.

JEL classification: G32, G34, G38

Key Words: Leadership structure; Firm valuation; Corporate governance; Managerial shareholdings

\footnotetext{
* This article draws on the findings in our recent papers "Should Chairman and CEO Be Separated? Leadership Structure and Firm Performance in Switzerland", forthcoming in the Schmalenbach Business Review, and "An Integrated Framework of Corporate Governance and Firm Valuation”, European Financial Management, Vol. 12 (2006), pp. 249-283 (co-authored with Stefan Beiner and Wolfgang Drobetz).

\# Corresponding author:

Tel.: +41-71-222-10-94; fax: +41-71-224-70-88. E-mail: markus.schmid @unisg.ch.

Address: Swiss Institute of Banking and Finance, University of St. Gallen, Rosenbergstrasse 52, CH-9000 St. Gallen, Switzerland.
} 
In the public debate about improving corporate governance practices, the issue of combining the functions of the chief executive officer (CEO) and chairman of the board received considerable attention in recent years. From a theoretical perspective, strong agency-theoretic arguments advocating a separation of decision and control functions in large corporations are flawed by practical arguments stressing the benefits of a combined function. Also, as discussed below, the empirical evidence focusing on U.S. companies is not conclusive. In this context empirical evidence from a country with a different practice of CEO succession and a much higher percentage of firms maintaining a permanent leadership structure with separated functions may provide important new insights with respect to the question whether one leadership structure should generally be preferred to the other one.

We fill this gap by investigating the valuation effects of leadership structure for a sample of 152 Swiss firms, among which, in 2002, only 29 firms - or 19.08\% - maintained a combined function while the rest of the sample separated the functions of the CEO and chairman. In Switzerland, the "Swiss Code of Best Practice for Corporate Governance” became effective in July 2002. In contrast to the Bacon Report in the U.S. and the Cadbury Report in the U.K., the Swiss Code of Best Practice does not recommend the separation of the two functions explicitly. Rather it requires the companies to "provide for adequate control mechanisms" if "for reasons specific to the company or because the circumstances relating to availability of senior management makes it appropriate”, the firm decides to combine the two functions. Nevertheless, in Switzerland the percentage of firms with separated functions is approximately $80 \%$ and remained fairly constant over the past 10 years.

Consistent with prior U.S. studies, we found no evidence of a systematic and significant difference in firm value between firms with combined and firms with separated functions. We also investigated whether firms with a poor corporate-governance structure are more likely to combine the two functions or whether, in contrary, firms with a combination of the two func- 
tions systematically use alternative governance mechanisms to counter-balance potential agency costs associated with their leadership structure. Consistent with the latter hypothesis, we found a similar curvilinear relationship between leadership structure and managerial shareholdings as between Tobin's Q and managerial shareholdings. Thus, possible agency costs associated with a combination of the functions are mitigated by a higher incentive alignment of the CEO/chairman through an adequate level of managerial shareholdings.

In light of the empirical evidence on the relation between leadership structure and firm value, the question arises whether regulatory efforts are the most efficient way to prompt firms towards the appropriate leadership structure. Another potentially more important mechanism, which may direct firms to choose the appropriate leadership structure, is the capital market. In fact, over the last few years corporate governance became an important investment criterion, which is for example reflected in the emergence of various corporate governance ratings. Moreover, a large body of academic literature on the relation between firm-level corporate governance and firm value emerged during the last few years. The majority of research finds that firms with better firm-level corporate governance rankings and disclosure standards exhibit higher Tobin’s Qs.

In this article, we also investigate whether firm value is significantly related to firm level corporate governance as measured by a broad survey-based index for a representative sample of Swiss firms. Consistent with prior research, we document a strong positive relation between our corporate governance index and firm value: Looking at the median firm, a one standard deviation increase in the corporate governance index causes an increase of the market capitalization by at least 12 percent of a company's book asset value. This result is robust to possible endogeneity, i.e., our analysis confirms that causation runs from corporate governance to firm value, but we also find evidence of reverse causality, with higher valued firms adopting better corporate governance practices. 


\section{Regulatory Environment and Common Practice}

Many countries have adopted codes of best practice only recently to establish guidelines for listed companies and to improve the overall quality of corporate governance. One issue that receives considerable attention and prompts regular controversies is the practice of combining the functions of the chief executive officer (CEO) and chairman of the board. In the U.S. for example, the "Report of the Conference Board Commission on Public Trust and Private Enterprise” issued on January 9, 2003, recommends that the CEO and chairman functions are separated and the position of the chairman is filled by an independent director. Already in 1992, the “Bacon Report on Corporate Boards and Corporate Governance” commissioned by the Conference Board recommended a separation of the CEO and chairman functions. Still, the percentage of firms with combined functions remained on a high level of approximately $80 \%$ of all large U.S. firms over the last two decades. ${ }^{1}$

In the U.K., the "Cadbury Report”, which strongly recommends a separated leadership structure, was issued in 1992. It is argued that the Cadbury report, which had a strong impact on U.K. governance practices in general, is one possible reason for the large decline in the fraction of U.K. firms with combined functions from $51.6 \%$ in 1985 to $9.8 \%$ in 1995 . $^{2}$ More recently, the "Review of the Role and Effectiveness of non-Executive Directors", authored by the well-known British investment banker Derek Higgs and commonly referred to as the "Higgs Report”, recommends not only the separation of the CEO and chairman positions but also that the chairman should be required to meet the standards of independence. ${ }^{3}$ The report was issued in January 2003 and some months later most of the recommendations were incor-

\footnotetext{
${ }^{1}$ See, for example, James A. Brickley, Jeffrey L. Coles, and Gregg Jarrell, "Leadership structure: Separating the CEO and chairman of the board,” Journal of Corporate Finance, Vol. 3 (1997), pp. 189-220, and Jay Dahya and Nickolaos G. Travlos, "Does the one man show pay? Theory and evidence on the dual CEO revisited," European Financial Management, Vol. 6 (2000), pp. 85-98.

${ }^{2}$ See, for example, Dahya and Travlos (2000) and Barry M. Craven and Claire L. Marston, "Investor relations and corporate governance in large UK companies," Corporate Governance - An International Review, Vol. 5 (1997), pp. 137-147.

${ }^{3}$ See p. 35 of the "Higgs Report" for a definition of independence. The report can be downloaded at: http://www.dti.gov.uk/cld/non_exec_review/
} 
porated into the U.K.'s “Combined Code of Practice”, with which all listed U.K. companies are required to comply or to explain the reasons for their non-compliance. ${ }^{4}$

In Switzerland, the "Swiss Code of Best Practice for Corporate Governance" became effective in July 2002. In contrast to the Bacon Report and the Cadbury Report, the Swiss Code of Best Practice does not recommend the separation of the two functions explicitly by stating: ${ }^{5}$ "The Board of Directors should determine whether a single person (with joint responsibility) or two persons (with separate responsibility) should be appointed to the Chair of the Board of Directors and the top position of the Executive Management (Managing Director, President of the Executive Board or Chief Executive Officer). If for reasons specific to the company or because the circumstances relating to availability of senior management makes it appropriate, the Board of Directors decides that a single individual should assume joint responsibility at the top of the company, it should provide for adequate control mechanisms. The Board of Directors may appoint an experienced non-executive member (“lead director”) to perform this task. Such person should be entitled to convene on his own and chair meetings of the Board when necessary.”

Nevertheless, in Switzerland the percentage of firms with separated CEO and chairman functions exceeds those documented for the U.S. (and U.K.) by far and amounts to approximately 80\%. Hence, the question arises whether the prevailing leadership structure in Switzerland reflects a long tradition, or whether it represents a recent trend due to increased pressure exerted by company regulators, shareholder activists, the press, and investors at large. To answer this question, we provide some information on the evolution of leadership structure of Swiss firms. Panel A of Figure 1 displays the percentage of firms with combined functions

\footnotetext{
${ }^{4}$ The "Combined Code - Principles of Good Governance and Code of Best Practice" was derived by the "Committee on Corporate Governance" from the "Committee's Final Report", the "Cadbury Report" and the "Greenbury Report” in May 2000.

${ }^{5}$ However, there is one exception: The „Swiss Banking Regulation“ requires a separation of the two functions for Swiss banks.
} 
over the 10-year period from 1993 to 2002 (black solid line with scaling on the left vertical axis). The sample includes all listed Swiss firms with information on leadership structure provided by the "Swiss Stock Guide" of the respective year. The number of firms included in the sample ranges from 210 to 247 (numbers in parentheses). It is apparent that the fraction of firms with combined functions is fairly constant over the whole 10-year period. When we restrict the analysis to the 131 firms, which are in our sample over the whole 10-year period, the picture remains basically unchanged (Panel B). We also investigate the frequency of changes in leadership structure in our sample firms. The percentage of firms switching from separated to combined (solid gray line with scaling on the right vertical axis) and from combined to separated functions (dotted gray line with scaling on the right vertical axis) are displayed in Panels A and B for all sample firms and for the 131 firms that stay in the sample for the full 10-year period, respectively. Most important, the graphs show that only a small part of sample firms change their leadership structure in a given year, whereas the frequency of changes from combined to separated functions increases somewhat towards the end of our sample period. 72 firms have separated and 10 firms have combined functions in all 10 sample years from 1993 to 2002.

[Insert Figure 1 about here]

\section{Shareholder Proposals and the Nestlé Case}

Over the last few years, an increasing number of U.S. firms has been asked to defend their reasons for not separating the CEO and chairman functions. For example, in January 2005, Walt Disney Co. agreed to separate permanently the functions of the CEO and chairman. The company acted in response to a shareholder proposal by the Connecticut Retirement Plans and Trust Funds. Disney’s CEO, M. Eisner, stepped down as chairman in 2004 after institutional investors mustered a 45\% "withhold" vote against him. In general, there has been a notable 
increase in the number of shareholder proposals requesting the separation of the two functions from 2002 (3 proposals) to 2003 (30 proposals) and 2004 (37 proposals). ${ }^{6}$ Moreover, there is evidence that a majority of directors favor a split. For example, McKinsey surveyed 180 U.S. directors representing 500 companies in 2002 and found that approximately $70 \%$ favored a separation of the two functions.

In Switzerland, the Nestlé case recently received considerable attention and prompted controversial discussions on leadership structure and corporate governance more general: In January 2005, Nestlé announced that the chairman of the board, R. Gut, would resign from the board and that the current CEO, P. Brabeck, would take over the function while staying CEO of the company. In addition, he was announced to become a member of Nestlé's Remuneration Committee, as well as a member of the Chairman's and Corporate Governance Committee, which handles nomination responsibilities. Brabeck moreover serves on the board of two other major Swiss companies, Credit Suisse and Roche Holding. Together with Nestlé, these firms represent about $38.52 \%$ of total market capitalization of the 27 blue-chip stocks included in the Swiss Market Index (as of January 2005).

Upon announcement, major shareholders, collectively represented by the Ethos Group, have submitted a proposal to include a clause in the articles of association that "the Chairman cannot simultaneously hold an exclusive function within the executive management”. The board of Nestlé has rejected this proposal. On a general level it was argued that the Swiss company law (Code of Obligations) allows a combination of chairman and executive function, and even the Swiss Code of Best Practice which became effective in July 2002 does not require separation. Moreover, it was argued that combining functions were common in many other countries such as the U.S. More specifically, Nestlé argued that the proposal would excessively constrain the company's flexibility which is not beneficial to its shareholders. The board also

\footnotetext{
${ }^{6}$ However, it is important to note that only very few of these proposals attained a majority vote. In 2004 for example, there was only one single case (Textron Inc.: 51.4\%) while the 37 proposals received average support from $28.3 \%$ percent of the votes cast.
} 
nominated two non-executive vice chairmen of the board in order to safeguard its independence. Finally, it was argued that it was impossible to appoint a new chairman among the board members due to the relative newness of the board. At least, the company admitted that it would be "ideal" to have separate offices, and that it does not intend to make the current structure permanent. This is, admittedly, reflected in the company’s history, where Nestlé had separate functions in 70 out of 82 years. In the most recent past, H. Maucher combined the positions from 1990-97. However, Brabeck reaches his mandatory retirement age in 2009 only, which gives him the opportunity to exercise his double-function for five years.

While it is true that the Swiss Code does not prohibit a combination of the two functions, it stipulates that the company must establish adequate control mechanisms. In this respect, having the CEO and chairman as a member of the remuneration committee represents a serious conflict of interest. Moreover, Nestlé maintains a voting limit restriction where voting rights are capped at 3 percent of the company's capital, which is a significant limitation of the company's governance structure. After all, one gets the impression of a poor succession planning on the level of the board of Nestlé, because Gut's mandatory demission was not an unexpected event.

Even though the shareholder proposal requesting the separation of the CEO and chairman functions at Nestlé did not pass, it is an important milestone in Switzerland's corporate governance discussion: It is arguably one of the first occasions on which shareholders organized themselves and demonstrated their disapproval of a company's decisions on the CEO and chairman succession. Moreover, the fact that P. Brabeck decided to resign from Nestlé's remuneration committee shows that the received $36 \%$ of the votes did not leave the company's decision makers completely unimpressed. 


\section{Dual Duality: The Case of Fritz Gerber}

There is an impressing Swiss case which highlights that the combination of the CEO and chairman functions is not necessarily related to poor firm performance: In 1977, F. Gerber became the CEO and chairman of Zurich Financial Services, one of Switzerland's largest insurance companies. Only one year later, he took over the CEO and chairman positions at Roche, one of the largest pharmaceutical companies worldwide. F. Gerber held these two combined CEO/chairman positions over a period of 14 years (1978-1991)! In 1991 he resigned from his executive function at Zurich and in 1995 from the board chair. Finally, in 1997 he resigned as CEO and in 2001 as chairman of Roche. As the figure below illustrates, this extensive and arguably unique accumulation of functions does not seem to have been associated with a poor company performance. It might be important to mention that F. Gerber additionally was a director on the board of various other large publicly traded companies during that time, including Alusuisse (1977-1981), Credit Suisse (1978-1996), Nestlé (1981-2001), and IBM Corp. (1989-1996). Not enough: He also served as a colonel in the Swiss army during this time period.

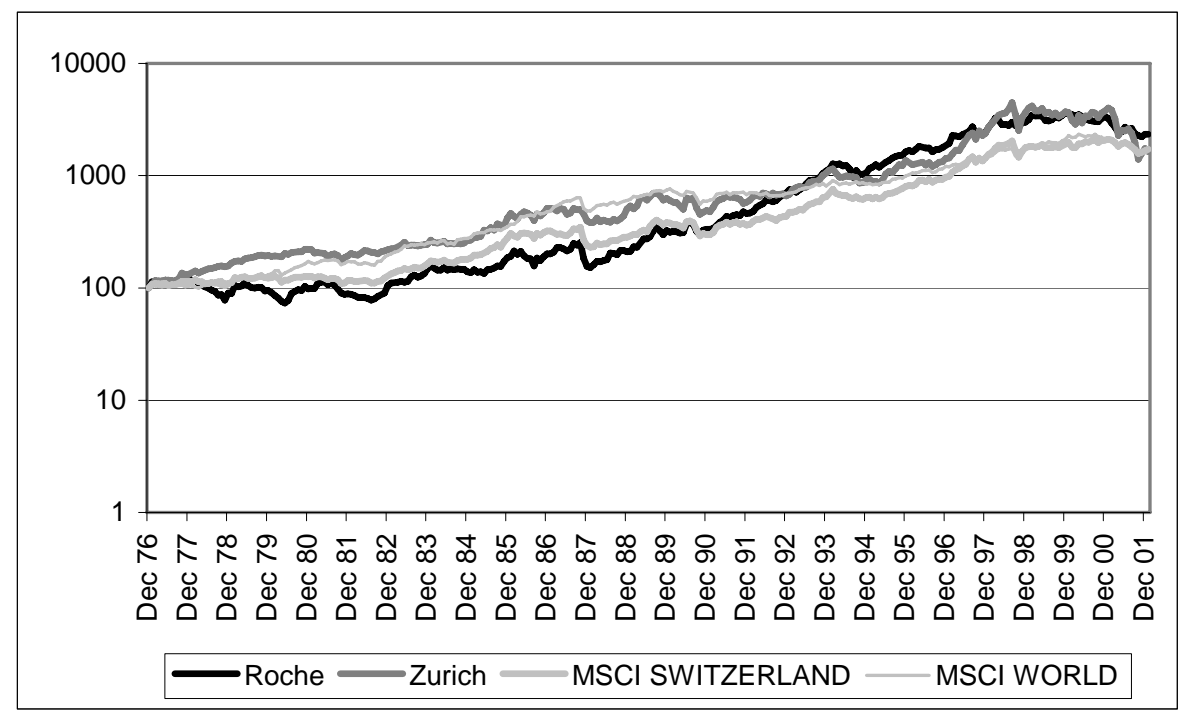

\section{The Academic Debate on Separating Management and Control}

Eugene Fama and Michael Jensen were among the first to argue that agency costs in large organizations can be reduced by a separation of decision management from decision control and that the board of directors is only an effective device for decision control if it limits the decision discretion of top managers. ${ }^{7}$ Extending this logic, Jensen recommended the separation of the CEO and chairman functions in his Presidential Address to the American Finance Association (p. 36): "The function of the chairman is to run board meetings and oversee the

\footnotetext{
${ }^{7}$ Eugene F. Fama and Michael C. Jensen, "Separation of ownership and control,” Journal of Law and Economics, Vol. 26 (1983), pp. 301-325.
} 
process of hiring, firing, evaluating, and compensating the CEO. Clearly the CEO cannot perform this function apart from his or her personal interest. Without the direction of an independent leader, it is much more difficult for the board to perform its critical function. Therefore, for the board to be effective, it is important to separate the CEO and chairman positions.”8 This attitude is also reflected in public discussions; it is argued that a leadership structure with combined functions might appear as if the CEO who is also chairman of the board grades his own homework.

Besides the reduction of the agency costs associated with controlling the CEO's behavior, there are also other reasons why a separation of the two functions might be beneficial to a firm. For example, an independent chairman may have important contacts to banks, the government, etc. and may provide valuable inputs based on his knowledge and experience often acquired in other organizations. However, there are also potential costs associated with a separation of the two functions:

1) Who monitors the monitors? New agency costs may arise with the delegation of decisions to the independent chairman as the non-CEO chairman is given enormous power, which again can be used to extract rents from firm. These costs can be reduced when the chairman holds equity in the firm.

2) There are information costs of transferring critical information between the CEO and the chairman. As a result of his function, the CEO presumably possesses considerable specialized knowledge, which is also valuable to the chairman. Hence, a separation of the two functions requires a costly and possibly incomplete transfer of information between the CEO and chairman.

3) While a combination of the two functions creates a clear-cut leadership and potentially a more rapid implementation of decisions, a separation of the CEO and chairman functions

\footnotetext{
${ }^{8}$ Michael C. Jensen, "Presidential address: The modern industrial revolution, exit, and the failure of internal control systems,” Journal of Finance, Vol. 48 (1993), pp. 831-880.
} 
might create the potential for rivalry between the two title holders. At the same time, a separation of the functions can make it more difficult to assign blame for bad company performance.

4) In the U.S., other potentially important costs are related to the common succession process of CEOs. In many firms with combined functions the CEO/chairman first passes the CEO title to his successor while retaining the chairman title during a probationary period in order to allow the board to monitor the new CEO on the job and to provide assistance and pass on important information to the new CEO. After the probationary period, the new CEO typically is assigned the additional title of chairman and the old chairman resigns from the board. The prospect of being promoted to chairman potentially provides important incentives to new CEOs, which are lost if a firm maintains an independent chairman.

Based on these arguments, it is unclear whether combining or separating the functions is beneficial to the firm and its shareholders. Both types of leadership structure are associated with different benefits and costs and the optimal choice depends on the relative weights of those. Moreover, since the benefits and costs associated with different leadership structures can vary across firms, so may the optimal leadership structure as well. Hence, the question whether the costs associated with combined functions outweigh the benefits is an empirical one. Unfortunately, the empirical evidence is also mixed. Some authors document that firms with separated functions outperform firms with combined functions, while other authors find exactly the opposite result. ${ }^{9}$ However, the majority of research finds no statistically significant difference in performance between firms with different leadership structures. ${ }^{10}$ Based on Michael Jensen and William Mecklings's framework of organizational structure, a possible explanation for these mixed findings could be that most firms have reached the optimal structure

\footnotetext{
${ }^{9}$ See, for example, Lynn Pi and Stephen G. Timme, “Corporate control and bank efficiency,” Journal of Banking and Finance, Vol. 17 (1993), pp. 515-530 and Lex Donaldson and James H. Davis, "Stewardship theory or agency theory: CEO governance and shareholder returns," Australian Journal of Management, Vol. 16 (1991), pp. 49-64.

${ }^{10}$ See, for example, Brickley, Coles, and Jarrell (1997).
} 
a long time ago and only depart from it when some of the cost components change. ${ }^{11}$ Hence, no differences in performance should be observed between different leadership structures and no abnormal stock returns should be realized on the day when a change in the leadership structure is announced. Consistently, there is evidence that firms do consider the costs and benefits of alternative leadership structures: A recent U.S. study finds that organizational complexity and CEO reputation increase the probability of combining the two functions. Similarly, a combination of the two functions is more likely when insider ownership is relatively large and the board is small. ${ }^{12}$ Based on these findings, pushing all firms to separate the CEO and chairman functions may be counterproductive and legislative reforms forcing separated functions may be misguided.

\section{Leadership Structure and Firm Value in Switzerland}

As the empirical evidence focusing on U.S. companies is not conclusive, empirical evidence from a country with a different practice of CEO succession and a much higher percentage of firms maintaining a permanent leadership structure with separated functions may provide important new insights with respect to the question whether one leadership structure should generally be preferred to the other one. In this section, we investigate whether firms with combined or separated functions differ systematically from each other and provide some evidence on the relation between leadership structure and firm value for a sample of 152 Swiss firms in 2002.

\section{The Data}

To identify a firm's leadership structure, we specified a dummy variable CEOCHAIR, which is equal to one if the chief executive officer (CEO) is also the chairman of the board of direc-

\footnotetext{
${ }^{11}$ Michael C. Jensen and William H. Meckling, "Specific and general knowledge, and organizational structure," Journal of Applied Corporate Finance, Vol. 8 (1995), pp. 4-18.

${ }^{12}$ Olubunmi Faleye, "Does one hat fit all? The case of corporate leadership structure”, Working Paper, Northeastern University, 2005.
} 
tors, and zero otherwise. To provide a comprehensive analysis of the overall structure of a firm's corporate governance, we included five different corporate governance mechanisms in our empirical analysis: SHAREOD is the sum of all shares owned by officers and executive as well as non-executive members of the board divided by the total number of shares outstanding. BLOCK is the percentage of cumulated voting rights exercised by outside blockholders with voting rights exceeding 5\%. BOARDSIZE is the number of directors on the firm's board. OUTSIDER refers to outside membership on the board, measured by the percentage of board seats held by directors without any executive function. LEVERAGE denotes firm leverage and was calculated as the ratio of total (non-equity) liabilities to total assets.

Our measure of firm valuation is Tobin's $Q$, and will be denoted by $Q$. We used a simple approximation of Tobin's Q estimated as the ratio of the market value of equity plus the book value of debt to the book value of total assets. ${ }^{13}$ To avoid that fluctuations in the market value of firms' equity influence our results, we computed the market value of equity as the mean of daily observations during 2002. Additionally, we employed 12 control variables in the different empirical analyses of this article.

As a starting point of our sample, we targeted all 235 firms (excluding investment companies) quoted at the Swiss Exchange (SWX) by the end of 2002. Complete data was available for 172 firms. The exclusion of eight obvious outliers reduced the sample to 164 firms. ${ }^{14}$ Finally, we excluded all 12 banks from the sample as they are required to separate the CEO and

\footnotetext{
${ }^{13}$ See, for example, Kee H. Chung and Stephen W. Pruitt, “A simple approximation of Tobin's q,” Financial Management, Vol. 23 (1994), pp. 70-74, and Steven B. Perfect and Kenneth W. Wiles, "Alternative construction of Tobin’s q - An empirical comparison,” Journal of Empirical Finance, Vol. 1 (1994), pp. 313-341.

${ }^{14}$ We excluded three firms for which the value of Tobin's Q, our measure of firm value, exceeds the mean value by more than three standard deviations, two firms with a leverage ratio bigger than one, and three firms for which the value of the return on assets is falling short of the mean value by more than three standard deviations.
} 
chairman function by the Swiss Banking Regulation, which left us with a sample of 152 firms. $^{15}$

Data was collected from different sources including Thomson Financial's Datastream and Worldscope and the "Swiss Stock Guide 2002/2003” and generally refers to the reporting period from January 2002 to December 2002. When necessary, the data was supplemented and verified consulting annual reports and web pages. Managerial ownership data (SHAREOD) was hand-collected from the 2002 annual reports.

\section{Do Firms with Combined and Firms with Separated Functions Differ from each other?}

Before addressing the effect of leadership structure on firm value, we used a multivariate probit regression framework to analyze whether firms with combined differ systematically from firms with separated functions. As the agency costs of a combination of the functions may be eased by alternative corporate governance mechanisms that help to align the interests of the $\mathrm{CEO} /$ chairman and the shareholders, we included the five corporate governance mechanisms along with a set of five control variables in this analysis. The control variables are: firm size as measured by the natural logarithm of the book value of total assets, average annual growth of sales over the past three years (2000-2002), R\&D intensity calculated as R\&D expenses over sales, profitability as measured by the ratio of operating income to total assets, and a dummy variable whether the company is issuing American Depositary Receipts.

The results are reported in Column 1 of Table 1 and reveal that, with the exception of OUTSIDER, there are no systematic differences between the corporate governance mechanisms adopted by firms with combined and firms with separated functions. The significantly negative coefficient on OUTSIDER is not very surprising as firms with the CEO as chairman exhibit a lower fraction of outside directors partly by construction. With respect to the control

\footnotetext{
${ }^{15}$ We also recalculated all results reported in the paper based on the larger sample including banks $(N=164)$ and found them to remain qualitatively similar. For example, in Table 1 there is not one single change in the significance level of any variable.
} 
variables, we find firms with combined functions to be characterized by lower $R \& D$ expenses and higher past sales growth rates. ${ }^{16}$

Several studies document a nonlinear relationship between managerial shareholdings and firm valuation. ${ }^{17}$ In fact, theoretical arguments are not conclusive about the sign of this relationship and predict positive (incentive alignment) as well as negative (voting control possibly leading to managerial entrenchment) effects of managerial shareholdings. ${ }^{18}$ It may thus be argued that up to a certain level, managerial shareholdings are a possible instrument to ensure that managers pursue the interests of shareholders. However, when controlling a substantial fraction of the firm's equity, officers and directors may have enough voting power or influence more generally to be immune to career concerns, monitoring by large shareholders, the discipline of the product market, and value-enhancing takeovers. Hence, when controlling enough voting rights, managers may expropriate minority shareholders and extract private benefits of control. Moreover, there is evidence of a nonlinear relationship between managerial shareholdings and the fraction of outside directors on the board indicating an incentive "alignment demand" for monitoring when managers own little stock and an "entrenchment-amelioration" demand when managerial shareholdings are high. ${ }^{19}$

In order to investigate whether there is a nonlinear relationship between CEOCHAIR and SHAREOD, we included a squared term of SHAREOD, denoted by SHAREOD2, in the previous regression equation. The results are reported in Column 2 of Table 1: While the coeffi-

\footnotetext{
${ }^{16}$ These results are robust to the inclusion of additional control variables including, for example, the age of the firm, a dummy variable for the existence of different share categories, and a dummy variable whether the state is a major shareholder of the firm. We also investigate whether a combination of the two functions is more common in firms, in which one of the founders is still in charge of either the CEO or chairman position. However, while positive, the relation is not statistically significant.

${ }^{17}$ See, for example, John McConnell and Henri Servaes, "Additional evidence on equity ownership and corporate value,” Journal of Financial Economics, Vol. 27 (1990), pp. 595-613. A recent study replicated the finding of a curvilinear relation between Tobin's Q and managerial shareholdings for a sample of Swiss firms: Markus M. Schmid and Heinz Zimmermann, "Managerial Incentives and Firm Valuation - Evidence from Switzerland", Working Paper, University of Basel, 2005.

${ }^{18}$ See, for example, Randall Morck, Andrei Shleifer, and Robert Vishny, "Management ownership and market valuation,” Journal of Financial Economics, Vol. 20 (1988), pp. 293-315.

${ }^{19}$ Kenneth V. Peasnell, Peter F. Pope, and Steven Young, "Managerial equity ownership and the demand for outside directors," European Financial Management, Vol. 9 (2003), pp. 231-250.
} 
cient on SHAREOD is statistically insignificant in Column 1, we now find evidence of a curvilinear relationship between CEOCHAIR and SHAREOD. Hence, on average firms with combined functions exhibit managerial shareholdings close to the optimal level. In fact, we find a maximum of $27.2 \%$ based on a probit and $30.0 \%$ based on a linear probability model for the relation between CEOCHAIR and SHAREOD, which is close to the value of $37.6 \%$ reported by McConnell and Servaes (1990) for the relationship between managerial shareholdings and Tobin's Q in the U.S. and the maximum value of 37.3\% for our Swiss sample as reported in the next section. This result suggests that possible agency costs associated with a combination of the two functions are mitigated by a higher incentive alignment of the CEO/chairman through adequate managerial shareholdings.

However, it is important to notice that SHAREOD comprises the shareholdings of all officers and directors. As a leadership structure with combined functions is especially vulnerable to entrenchment by the CEO/chairman, it would be particularly interesting to investigate the shareholdings of the $\mathrm{CEO} /$ chairman in firms with combined functions and compare them to those of CEOs and chairmen in firms with separated functions. While Swiss firms are not obliged to report individual shareholdings of the CEO and/or chairman of the board, the requirement to disclose all shareholdings exceeding $5 \%$ allows us to construct a variable SHAREOD5\% including all block shareholdings of individuals holding either the CEO title, the chairman title, or both. In fact and consistent with our hypothesis, the results in Column 3 of Table 1 reveal that the probability of having a combination of the two functions is positively associated with SHAREOD5\% indicating that CEO/chairmen are more likely to hold substantial blocks of their “own” companies' shares than CEOs and chairmen in firms with separated functions.

We summarize the results of this section as follows: We find no evidence that firms with a poor corporate-governance structure are more likely to have combined functions. In contrary, 
firms with combined functions seem to counter-balance potential agency costs evolving from their leadership structure: The curvilinear relation between CEOCHAIR and SHAREOD indicates that possible agency costs associated with a combination of the two functions are mitigated by a higher incentive alignment of the CEO/chairman through managerial shareholdings.

[Insert Table 1 about here]

\section{Leadership Structure and Firm Value}

We finally investigated the valuation consequences of leadership structure in a multivariate OLS framework in order to control for other potentially important determinants of firm value besides CEOCHAIR. In the first regression specification, we included six control variables. Two variables aim to control for growth opportunities: firm size as measured by the natural logarithm of total assets and average annual growth of sales over the past three years (20002002) ${ }^{20}$ We expect a positive relationship between past growth and $Q$ and a negative influence of firm size on $Q$, because growth opportunities tend to be lower for larger firms. To control for firm-specific knowledge and growth opportunities, we included R\&D intensity. Based on simple valuation models, $Q$ may additionally depend on profitability as measured by the return on assets and the company stock's market beta. Finally, to control for industry effects, we included 13 dummy variables into the regression equation. In a second specification, we additionally included the five corporate governance mechanisms for the following two reasons: First, a voluminous literature suggests that different corporate governance mechanisms affect firm value through a reduction of agency costs. ${ }^{21}$ Second, the agency costs of a

\footnotetext{
${ }^{20}$ See, for example, David Yermack, "Higher market valuation of companies with a small board of directors," Journal of Financial Economics, Vol. 40 (1996), pp. 185-211.

${ }^{21}$ See, for example, Paul A. Gompers, Joy L. Ishii, and Andrew Metrick, "Corporate governance and equity prices,” Quarterly Journal of Economics, Vol. 118 (2003), pp. 107-155.
} 
combined CEO-chairman function may be mitigated by the use of alternative corporate governance mechanisms.

The results for the two specifications can be found in Columns 4 and 5 of Table 1, respectively. Most important, the coefficient on CEOCHAIR is negative but statistically insignificant in both specifications. Hence, despite the fundamental differences between leadership structures in the U.S. and Switzerland, our results are consistent with the majority of prior research on the valuation consequences of leadership structure in the U.S. ${ }^{22}$ Column 5 reveals that of all five corporate governance mechanisms only SHAREOD and its squared term, SHAREOD2, are statistically significant indicating a curvilinear relationship between managerial shareholdings and firm value. Together with the curvilinear relationship between CEOCHAIR and SHAREOD found in Column 2, this result suggests that possible agency costs associated with combined functions are mitigated by a higher incentive alignment of the CEO/chairman through an adequate level of managerial shareholdings.

For illustrative purposes, the curvilinear relations between the probability that a firm combines the CEO/chairman functions and managerial shareholdings (SHAREOD) as well as between Tobin's Q and managerial shareholdings are displayed graphically in Figure 2. The black line represents the relation between $Q$ and SHAREOD (the respective scaling is on the left y-axis). The dark-gray line depicts the relation between CEOCHAIR and SHAREOD based on a least square estimation of the quadratic regression specification reported in Column 2 of Table 1 . The scaling on the right y-axis reveals the major flaw of the linear probability model as the predicted probabilities drop below zero for large values of SHAREOD. Fi-

\footnotetext{
${ }^{22}$ To investigate whether the affiliation of the chairmen who do not serve as CEOs has valuation effects, we disaggregated the variable $C E O C H A I R=0$ into four dummy variables, depending whether the chairman is a 1) former CEO of the firm, 2) major shareholder, 3) (co-)founder of the firm or belongs to the founding family, or 4) a representative of another company which is a major shareholder of the firm. We included the four dummy variables into the regression equation reported in Column 5 of Table 1 . However, all four coefficients are insignificant while all other coefficients remain basically unchanged. The coefficient on the dummy variable whether the chairman is a major shareholder has the lowest $p$-value (0.27) and is the only negative coefficient out of the four. This indicates potential private benefits of control associated with a chairman who is a major shareholder of the firm.
} 
nally, the light gray line displays the predicted probabilities that a firm combines the two functions based on the marginal effects of the probit estimation reported in Column 2 of Table 1. The relation between CEOCHAIR and SHAREOD reaches a maximum for SHAREOD equal to $27.2 \%$ based on the probit model, and $30.0 \%$ based on the linear probability model. The value of SHAREOD which maximizes $Q$ is $37.3 \%$. Approximately $86.8 \%$ (93.4\%) of the sample lies in the ownership range of $0 \%$ to $50 \%$ (0\% to $60 \%){ }^{23}$

[Insert Figure 2 about here]

In summary, consistent with the majority of prior research on leadership structure in the U.S., the evidence in this section reveals no systematic and significant difference in firm value between firms with combined and firms with separated functions. Moreover, the finding of a significant curvilinear relationship between Tobin's Q and SHAREOD and a similar relationship between CEOCHAIR and SHAREOD suggests that possible agency costs associated with a combination of the two functions are mitigated by a higher incentive alignment of the $\mathrm{CEO} /$ chairman through an adequate level of managerial shareholdings.

\section{The Emergence of Corporate Governance Ratings}

In light of the empirical evidence provided above, the question arises whether regulatory efforts are the most efficient way to prompt firms towards the appropriate leadership structure. In fact, one should expect that the capital market is a potentially important mechanism which may direct firms to choose the appropriate leadership structure. From a theoretical point of view, agency problems affect the value of firms through the expected cash flows accruing to

\footnotetext{
${ }^{23}$ To further investigate the nonlinear relation between CEOCHAIR and SOD as well as $Q$ and SOD, we additionally estimated piecewise regressions as suggested by Morck, Shleifer, and Vishny (1988). Besides their original breakpoints of $5 \%$ and $25 \%$, we tested a series of alternatives including $10 \%$ and $30 \%, 15 \%$ and $35 \%$, as well as $20 \%$ and $40 \%$. Most importantly, none of the coefficients is statistically significant. However, the results are consistent with those reported in Columns 2 and 5 of Table 1 as the coefficients on the different piecewise $S O D$-variables follow the pattern suggested by Figure 2 and always exhibit the same sign for CEOCHAIR and $Q$ (with one expected exception as the maximizing value of $S O D$ is somewhat smaller for CEOCHAIR than for $Q$ ).
} 
investors and/or the cost of capital. Specifically, agency problems make investors pessimistic about future cash flows while good corporate governance decreases the cost of capital to the extent that it reduces shareholders' monitoring and auditing costs. With the emergence of corporate governance ratings, a firm's corporate governance developed from a "soft" concept to an important and established investment criterion. ${ }^{24}$ For example, a study released by McKinsey and Company in 2002 reports that investors are willing to pay an average premium of $14 \%$ for the stock of well-governed companies. Similarly, a large body of academic literature on the relation between firm-level corporate governance and firm value emerged during the last few years. The majority of research finds that firms with better firm-level corporate governance rankings and disclosure standards exhibit higher Tobin’s Qs. ${ }^{25}$

In this section we investigate whether firm value is significantly related to firm level corporate governance as measured by a broad survey-based index for a representative sample of Swiss firms. Switzerland is a particularly interesting case to analyze. The institutionalization of shareholdings, i.e., the accumulation of stocks by professional asset managers, had strong effects on the structural changes of the equity market after pension plans became mandatory in the mid-eighties and emerged as the major domestic investment force thereafter. Moreover, in the course of globalization of equity markets many restrictions protecting the management of Swiss firms were abandoned, such as restrictions on the transferability or ownership of shares ("Vinkulierung”) or multiple share classes with limited or unequal voting rights. These developments make it interesting to investigate the role of specific control mechanisms in more detail.

\footnotetext{
${ }^{24}$ For example, Deminor, GovernanceMetrics International, Moody's, and Standard \& Poors rate U.S. and international companies based on the quality of their corporate governance.

${ }^{25}$ See, for example, Gompers, Ishii, and Metrick (2003) for U.S. evidence and Leora F. Klapper and Inessa Love, “Corporate governance, investor protection, and performance in emerging markets", Journal of Corporate Finance, Vol. 10 (2004), pp. 703-728, for emerging markets evidence. One of the few European studies is: Wolfgang Drobetz, Andreas Schillhofer, and Heinz Zimmermann, “Corporate governance and expected stock returns: Evidence from Germany”, European Financial Management, Vol. 10 (2004), pp. 267-293.
} 


\section{The Construction of a Corporate Governance Index for Switzerland}

The corporate governance index (CGI) is based on responses to a detailed questionnaire, which refers to the recommendations in the Swiss Code of Best Practice. The survey was sent out to all Swiss firms quoted at Swiss Exchange (SWX) with the exception of investment companies and was completed between May and July 2003. When necessary, the data was supplemented and verified consulting annual reports and web pages. The survey consisted of 38 questions/attributes in five categories: (1) corporate governance commitment, (2) shareholders’ rights, (3) transparency, (4) board of directors and executive management, and (5) auditing and reporting. To qualify for inclusion, an attribute must refer to a governance element that is not (yet) legally required. All attributes can be initiated and implemented by a firm’s decision makers.

The construction of the index is straightforward: First, firms were asked to indicate their acceptance level by assigning a value between 1 (minimum) and 5 (maximum) to each question. One point is added for each subsequent acceptance level on this five-scale answering range. A higher acceptance level is interpreted as an (earlier) active move by the firm's decision makers to improve its corporate governance system. Second, we computed the simple sum over all 38 questions. While such a simple weighting scheme makes no attempt to accurately reflect the relative importance of the individual governance attributes, it has the advantage of being transparent and easy to interpret. Finally, the index was normalized to have a value between 0 and 100, with better-governed firms having higher index levels.

120 out of 235 firms returned the questionnaire, which implies a response rate of $51.06 \%$. We had to drop 11 firms due to insufficient data leaving a final sample of 109 firms for the analysis in this section. The distribution of the index is displayed in Figure 3. The mean of CGI is 58.46 and the median 59.21, indicating a relatively symmetric distribution. Not surprisingly, the blue chip firms included in the Swiss Market Index (SMI) have significantly higher values 
of CGI than the other firms in our sample. Additionally, Figure 3 reveals that there are substantial differences in firm-level corporate governance between the 109 firms in our sample: the minimum value is 25.00 , and the maximum value is 90.13 .

[Insert Figure 3 about here]

\section{Corporate Governance and Firm Value: A Problem of Endogeneity}

Given that a firm's decision makers can choose from a broad menu of alternative corporate governance mechanisms, one may suspect that there are substitution effects. Specifically, the greater use of one mechanism needs not be positively related to firm performance, and where one mechanism is used less, others may be used more, resulting in equally good performance. Hence, the existence of alternative governance mechanisms and their likely interdependence make ordinary least squares regressions that relate the use of any single governance mechanism to firm performance difficult to interpret. We tried to avoid a potential missing variables bias and control for possible interrelationships between the different corporate governance mechanisms and Tobin's $Q$ by including in the analysis additional mechanisms that are not contained in the index. They are specified by the following variables: the percentage of voting rights exercised by the largest shareholder (LSHARE), the percentage of cumulated voting rights exercised by true outside blockholders (BLOCKOUT), i.e., non-group listed companies, mutual funds, and pension funds with voting rights exceeding 5\%, the number of directors on the board (BOARDSIZE), the percentage of outside members on the board (OUTSIDER), and firm leverage (LEVERAGE).

To take into account a possible endogeneity of our corporate governance index (CGI), the five additional governance mechanisms, and Tobin's Q, we specified a simultaneous equations system where each governance mechanism is the dependent variable in one of the equations. While the choice of any of the five governance mechanisms may depend upon choices of the 
other four, these choices will depend on other factors as well. Thus, each equation includes all other governance mechanisms and additional exogenous control variables as explanatory variables. To investigate the effect of the different governance mechanisms on firm valuation, a seventh equation with Tobin's Q as dependent variable was added to the system. By the same time, Tobin's Q was included as an explanatory variable in the other six equations of the system to allow for possible interrelations between the governance mechanisms and Tobin's Q. The system of seven simultaneous equations is displayed schematically in Panel A of Figure 4. Panel B displays the seven equations whereas CGM refers to the six corporate governance mechanisms with the exception of the governance mechanism on the left-hand side of the equation (equations 1 to 6 ) and Controls to a set of exogenous control variables.

\section{[Insert Figure 4 about here]}

The system was estimated using three-stage least squares (3SLS). For sake of brevity, we abstain from reporting the results in a table; they are discussed in more detail in our European Financial Management article. ${ }^{26}$ We find strong evidence supporting the hypothesis that corporate governance is positively related to firm value. Specifically, for the median firm, a one standard deviation increase in the corporate governance index causes an increase of the market capitalization by at least 12 percent of a company's book asset value. It turns out that this effect is about six times stronger in the 3SLS system than in a simple OLS setting. As it is hard to find persuasive arguments for such an enormous difference, we are hesitant to exactly quantify the valuation impact of improved governance standards, and interpret the (biased) OLS coefficient on CGI as a lower limit. ${ }^{27}$ Our results further reveal that neither the presence of a controlling shareholder nor large (outside) blockholders have a significant valuation impact. We also found statistically significant effects between the governance mechanisms

\footnotetext{
${ }^{26}$ See Beiner, Drobetz, Schmid, and Zimmermann (2006).

27 An extensive discussion of possible explanations for the large difference between the OLS and 3SLS coefficients is provided by Beiner, Drobetz, Schmid, and Zimmermann (2006).
} 
which highlights the endogeneity issue and justifies the simultaneous equations approach. For example, firms with a controlling shareholder tend to have larger boards and a smaller fraction of outside directors, indicating private benefits from sitting on the board.

\section{Conclusions}

In the past years, many countries have adopted guidelines or rules to improve the quality of corporate governance for listed companies. One field of enduring controversies among practitioners and academics is the practice of combining the functions of the CEO and the chairman of the board. Agency-theoretic arguments advocating a separation of the functions are flawed by practical arguments stressing the benefits of a combined function. In addition, the empirical evidence from U.S. companies is not conclusive. We therefore supply evidence from a country with a different practice of CEO succession and a much higher percentage of firms with separated functions. We analyzed this issue within the context of the general governance structure of firms, as reflected by the various governance mechanisms available to the shareholders. Despite of the institutional difference between the two countries, our results are consistent with the empirical findings for U.S. firms: We found no evidence of a systematic and significant difference in firm value between firms with combined and firms with separated functions. We also investigated whether firms with a poor corporate governance structure are more likely to have a combination of the two functions or whether, in contrary, firms with

combined functions systematically adopt alternative governance mechanisms to counterbalance potential agency costs associated with a combination of the two functions. Consistent with the latter hypothesis, we found a similar curvilinear relationship between leadership structure and managerial shareholdings as between Tobin's Q and managerial shareholdings. Apparently, potential agency costs associated with a combination of the two functions are mitigated by a higher incentive alignment of the CEO/chairman through an adequate level of managerial shareholdings. 
In light of these empirical findings, the question arises whether regulatory efforts are the most efficient way to improve their leadership structure, or whether the capital market provides the relevant incentives. We therefore investigated whether firm value is significantly related to the quality of corporate governance as measured by a broad survey-based index. We controlled for reverse causality between the index, some additional (or complementary) governance mechanisms and firm value (Tobin's Q) by estimating a system of simultaneous equations by 3SLS. We found strong evidence supporting the hypothesis that our corporate governance index is positively related to firm value. In contrast, neither the presence of a controlling shareholder nor large outside blockholders have a significant valuation impact.

Two implications emerge from our analysis: First, the existing empirical evidence does not support arguments advocating a legal or statutory separation of the CEO-chairman leadership functions in publicly traded firms. Companies can chose their own "mix" among alternative control mechanisms to restrict the potential damage for shareholders' wealth. In this perspective, there is no case for observing a valuation discount or to require regulatory actions. Second, our results highlight the pivotal role of the capital market for providing incentives to improve governance standards. This does not imply that investor protection and prosecution capabilities are useless. Although the task of reforming investor protection laws and improving judicial quality is a lengthy process that requires the support of many interest groups, it seems like a worthwhile objective in the public interest. However, once adequate disclosure and transparency standards are in place, our empirical results suggest that it is ultimately the capital market that rewards good governance practices and punishes bad ones. In other words, corporate governance should be understood as a chance rather than an obligation from the perspective of a firm’s decision makers. 
Table 1: Probit and OLS Regression Results

\begin{tabular}{|c|c|c|c|c|c|}
\hline & & & ependent Variabl & & \\
\hline & CEOCHAIR & CEOCHAIR & CEOCHAIR & $Q$ & Q \\
\hline & (1) & (2) & (3) & (4) & (5) \\
\hline C & 2.939 & 1.939 & 2.283 & 0.803 & 0.746 \\
\hline & $(0.164)$ & $(0.388)$ & $(0.255)$ & $(0.349)$ & $(0.501)$ \\
\hline CEOCHAIR & & & & -0.020 & -0.122 \\
\hline & & & & $(0.867)$ & $(0.418)$ \\
\hline SHAREOD & 0.023 & 6.667 * & & & 1.497 ** \\
\hline & $(0.979)$ & $(0.052)$ & & & $(0.030)$ \\
\hline SHAREOD2 & & -12.248 * & & & -2.008 ** \\
\hline & & $(0.056)$ & & & $(0.027)$ \\
\hline SHAREOD5\% & & & 1.861 ** & & \\
\hline & & & $(0.024)$ & & \\
\hline BLOCK & -0.965 & -0.430 & -0.126 & & -0.297 \\
\hline & $(0.261)$ & $(0.641)$ & $(0.890)$ & & $(0.107)$ \\
\hline BOARDSIZE & 0.059 & 0.041 & 0.052 & & 0.008 \\
\hline & $(0.497)$ & $(0.656)$ & $(0.546)$ & & $(0.723)$ \\
\hline LEVERAGE & 1.077 & 1.085 & 0.838 & & 0.116 \\
\hline & $(0.299)$ & $(0.310)$ & $(0.418)$ & & $(0.642)$ \\
\hline OUTSIDER & $-7.857^{\star \star \star *}$ & -7.096 *** & -7.656 *** & & -0.269 \\
\hline & $(0.000)$ & $(0.000)$ & $(0.000)$ & & $(0.524)$ \\
\hline Control Variables & included & included & included & included & included \\
\hline Industry Dummies & included & included & included & included & included \\
\hline Wald Test & 23.924 *** & $25.737^{\star \star \star *}$ & $25.805^{\star \star *}$ & 9.744 & $24.345^{* *}$ \\
\hline & $(0.008)$ & $(0.007)$ & $(0.004)$ & $(0.136)$ & $(0.018)$ \\
\hline McFadden $\mathrm{R}^{2}$ & 0.341 & 0.370 & 0.375 & & \\
\hline Adjusted $\mathrm{R}^{2}$ & & & & 0.324 & 0.339 \\
\hline
\end{tabular}

This table presents estimates from probit regressions of CEOCHAIR on different corporate governance mechanisms and control variables (Columns 1 to 3). Columns 4 and 5 report OLS regressions of Tobin's $\mathrm{Q}$ on a dummy variable whether the CEO is also the chairman of the board (CEOCHAIR), different corporate governance mechanisms and control variables. Included control variables in Columns 1 to 5 are: firm size as measured by the natural logarithm of total assets, average annual growth of sales over the past three years (2000-2002), R\&D intensity calculated as R\&D expenses over sales, and profitability as measured by the ratio of operating income to total assets. Columns 1 to 3 additionally include a dummy variable whether the company is issuing American Depositary Receipts and Columns 4 and 5 the company stock's market beta. The sample size is 152 . The numbers in parentheses are probability values for two-sided tests. $* * * / * * *$ denotes statistical significance at the $10 \% / 5 \% / 1 \%$ level. 
Figure 1: The Evolution of Leadership Structure in Switzerland from 1993 to 2002

Panel A: All Sample Firms

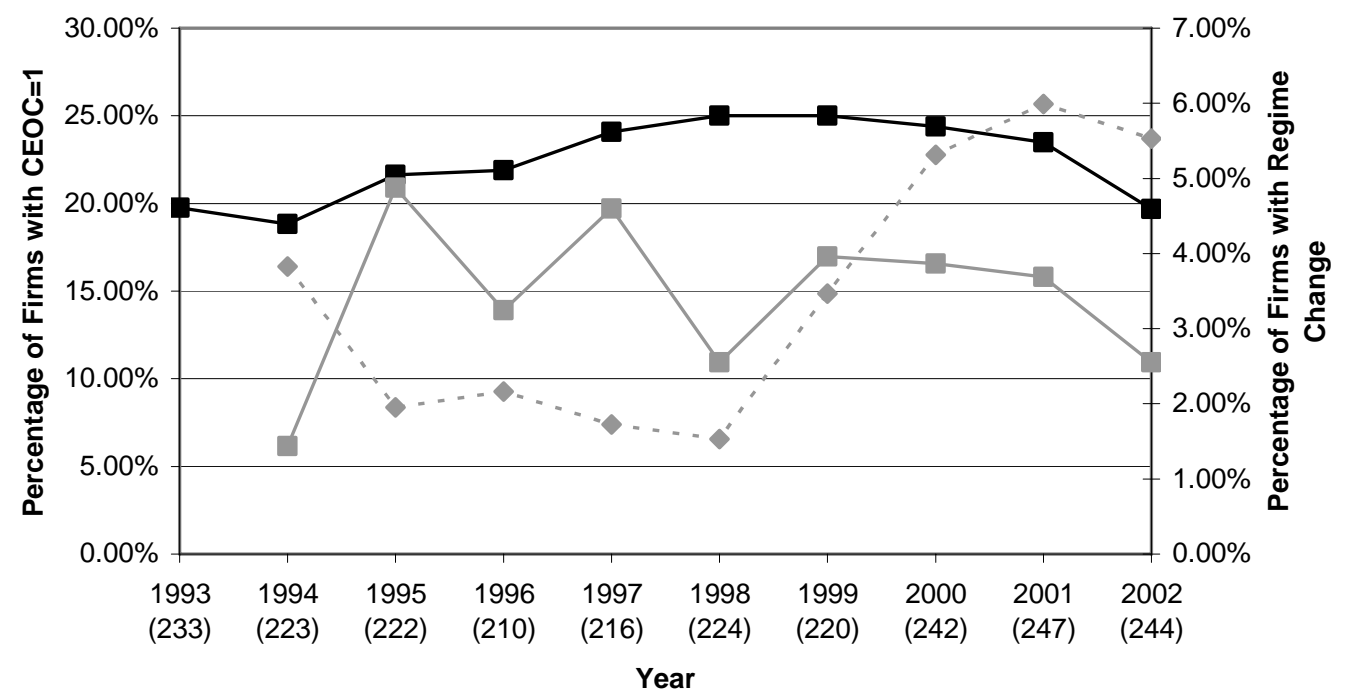

$\longrightarrow$ Combined Function (\%)——C Change (Combination) - - - Change (Separation)

Panel B: Firms with Complete Data for the Full 10-Year Period (N=131)

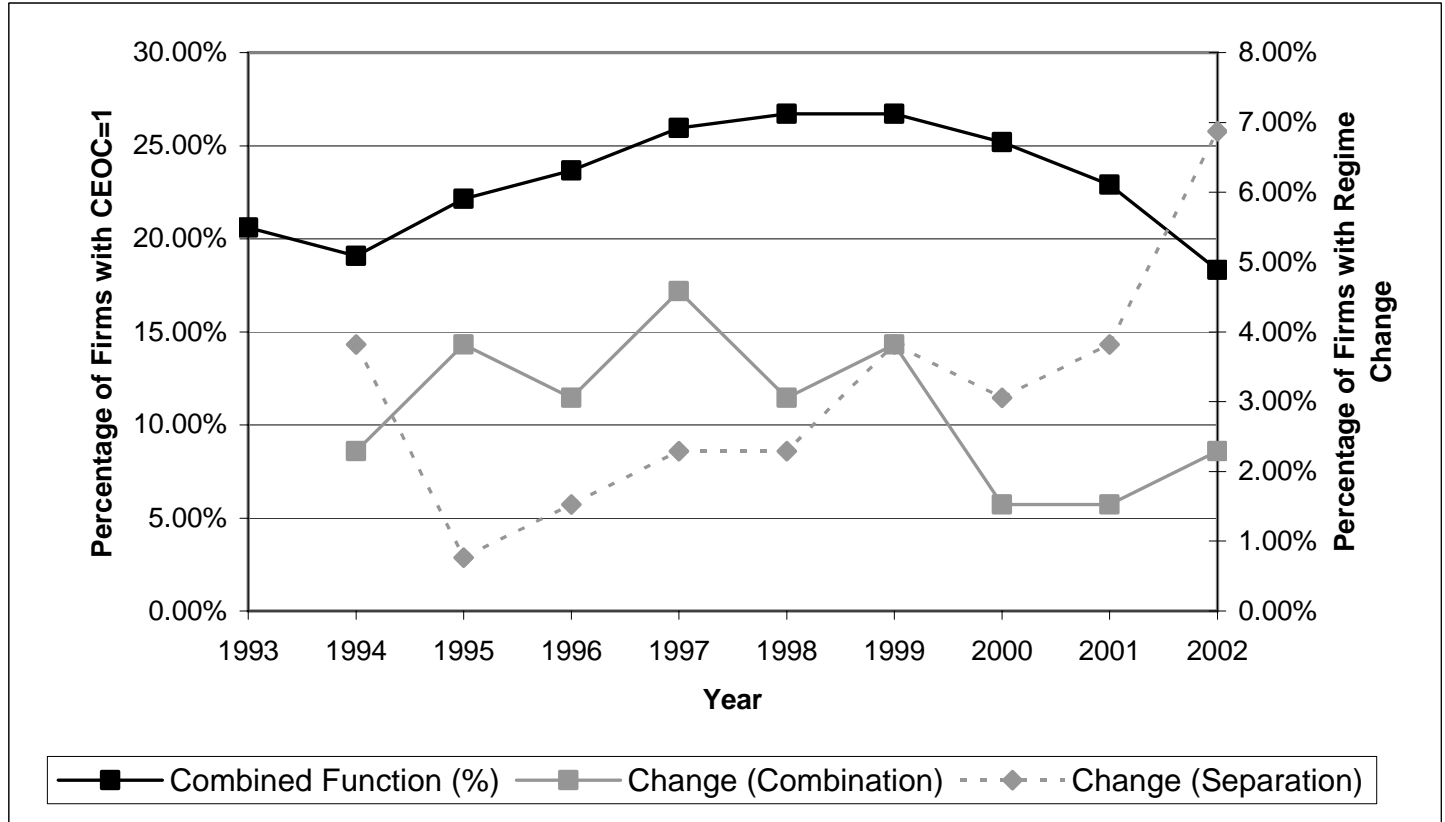


Figure 2: Nonlinear Relationship between Managerial Shareholdings (SHAREOD) and Leadership Structure (CEOCHAIR), as well as Managerial Shareholdings (SHAREOD) and Firm Value $(Q)$

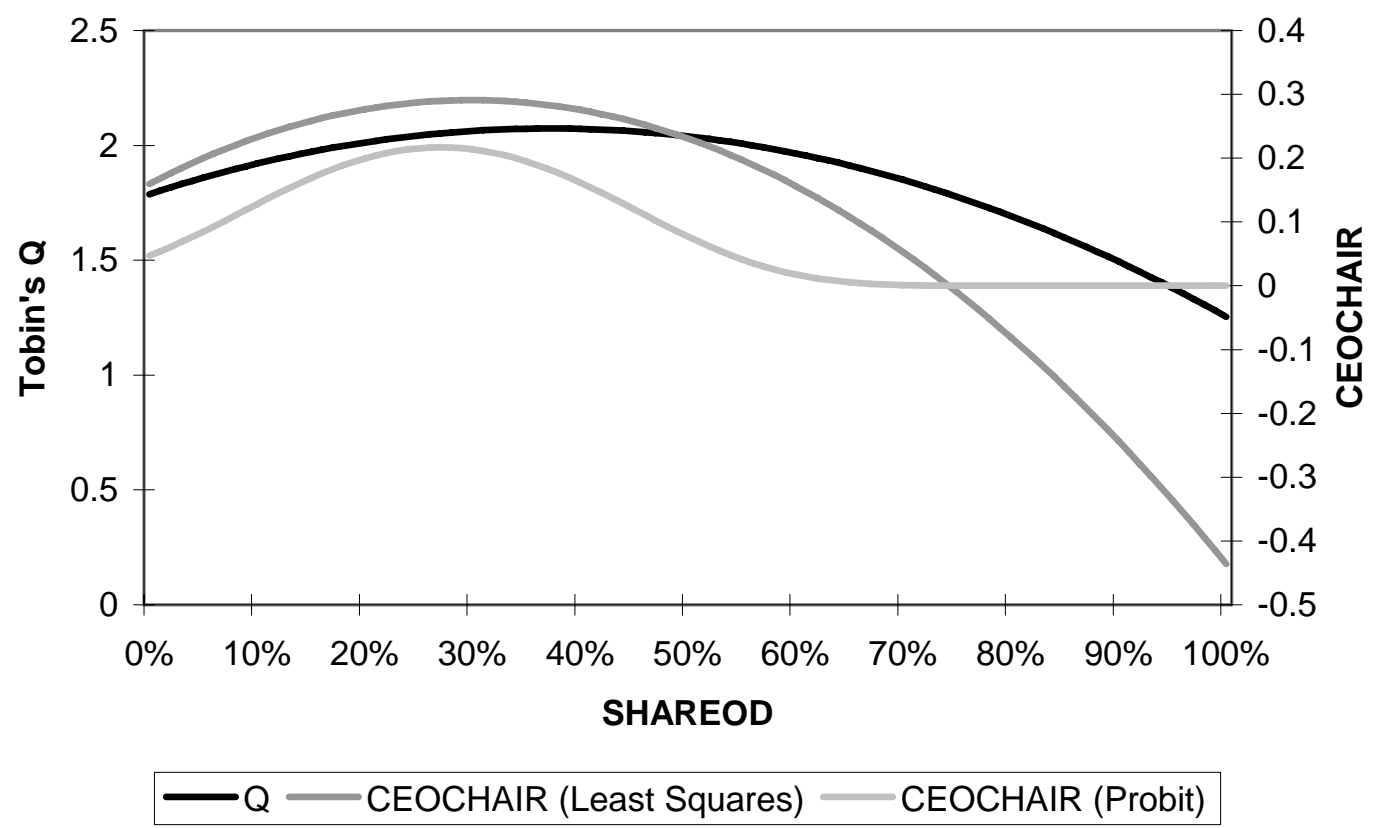


Figure 3: Empirical Distribution of the Corporate Governance Index (CGI)

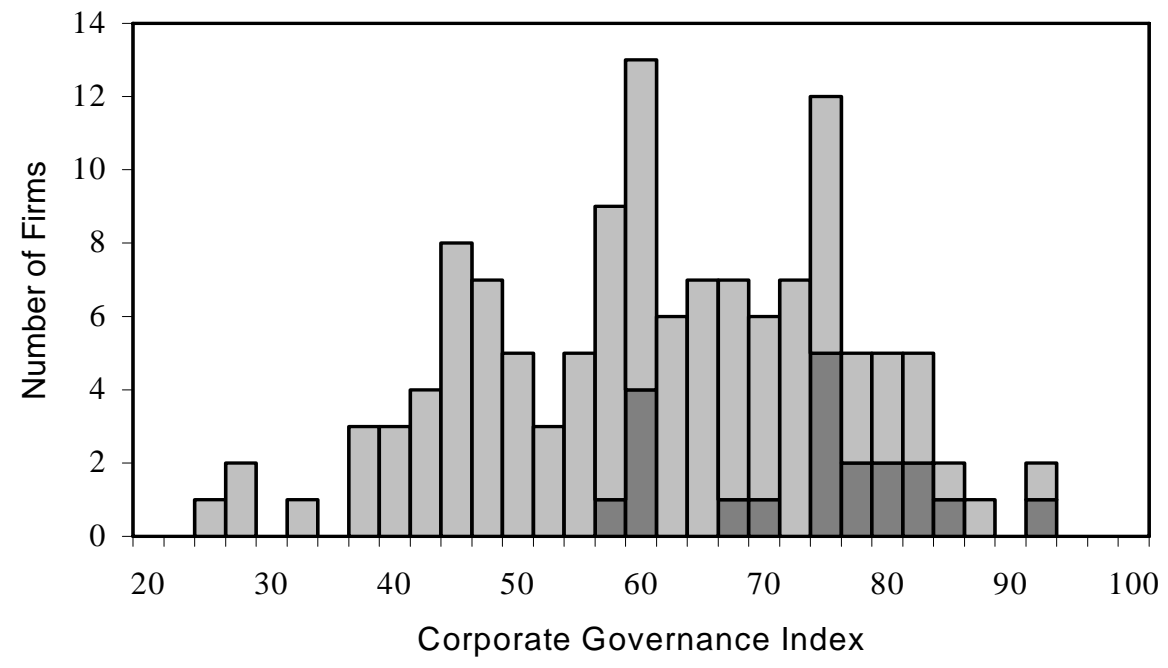

$\square$ SMI Firms $\square$ All Firms 
